\title{
ORGANIZATIONAL, REGULATORY AND LEGAL ASPECTS OF EUROPEAN INTEGRATION OF HIGHER MEDICAL EDUCATION IN UKRAINE: A CRITICAL REVIEW
}

DOI: 10.36740/WLek202006141

\author{
Valeria G. Marichereda' ${ }^{1}$, Svitlana B. Melnyk² ${ }^{2}$ Viktoriia I. Borshch ${ }^{3}$, Olena 0. Terzi ${ }^{1}$, Natalia A. Lyakhova ${ }^{4}$ \\ 'ODESA NATIONAL MEDICAL UNIVERSITY, ODESA, UKRAINE \\ 2NATIONAL UNIVERSITY «ODESA LAW ACADEMY», ODESA, UKRAINE \\ ${ }^{3}$ ODESA I. I. MECHNIKOV NATIONAL UNIVERSITY, ODESA, UKRAINE \\ ${ }^{4}$ UKRAINIAN MEDICAL STOMATOLOGICAL ACADEMY, POLTAVA, UKRAINE
}

\begin{abstract}
The aim: The main purpose of this research is to conduct the theoretical and applied study of the legal profile enforcement for state attestation of medical graduates, the relevant legislative system, and its effectiveness; to identify the issues of special legislative requirements, as well as the search for ways to resolve it.

Materials and methods: Basic methods: analysis, synthesis and comparison. Object of research: system of state certification of graduates of medical sciences. Investigation of this topic in the paper is carried out in the following logical sequence: firstly, the basic principles of the state integrated qualification exam were determined and analyzed; then the legal enforcement for integrated state qualification exam of master's degree in discipline "22 Health Care" was considered. Also, a critical review of Ukrainian normative base for holding the state attestation of medical graduates was conducted.

Conclusions: In view of foregoing, we can make a conclusion that in the modern globalization world, competition of national educational services should be ensured by a range of different activities: legal, organizational, financial, etc. The legal direction, domestic rules should correspond to similar, uniform rules and practices of the most effective state (regional, international) systems.
\end{abstract}

KEY WORDS: state attestation of medical graduates, higher medical education, organizational and legislative requirements for the qualification exam, competitiveness of higher medical education

Wiad Lek. 2020;73(6):1290-1295

\section{INTRODUCTION}

Reforming the healthcare sector in Ukraine, bringing it into line with current world standards, requires first and foremost a change in the training of medical personnel. Implementation of the principles of evidence-based medicine in medical and preventive activities, using of the latest techniques and medicines, ability and desire to use information and computer technologies, the desire to learn something new is what society expects and expects from young doctors. However, this new qualitative level of medical personnel is possible only under the conditions of radical changes in higher medical education and its successful integration into a common European educational space.

The introduction and implementation of reforms in higher medical education entails a restructuring of the educational process system, its content, teaching methods and technologies themselves, development of common criteria and standards according to the basic documents of the Bologna Agreements. The ultimate goal of these transformations is the formation of a common European educational and scientific space. In the context of globalization, there is competition in the field of human resources between providers of educational services in the world, including in the medical, so the priority of training a highly qualified specialist is the quality of education services both in the undergraduate stage and throughout life.

Integrated state qualification exam is a new complex attestation of medical students' substantive knowledge. It was introduced in 2019 as a cutting-edge tool for evaluating medical students' educational level, which should meet the needs of the main stakeholders in the healthcare systems. So, graduates are highly qualified professionals, prepared for the expanding and changing healthcare environment that they will step into. Patients will gain benefits by obtaining more compassionate care with better healthcare outcomes. Community receives the medical education system, which meets societal needs for highly professional health workers. Higher medical institutions have possibility to create the educational environment, focusing on skill approach training.

\section{THE AIM}

The main goal of this paper is theoretical and applied study of the legal profile enforcement for state attestation 
of graduates of higher medical schools, the relevant legislative system, and its effectiveness; identification of issues of special legislative requirements, as well as the search for ways to resolve it.

\section{MATERIALS AND METHODS}

Analysis, presented in this paper, was conducted in two parts. Firstly, the basic principles of the state integrated qualification exam were determined and analyzed; then the legal enforcement for integrated state qualification exam of master's degree in discipline " 22 Health Care" was considered. The object of research is the system of state attestation of medical graduates.

The key methods used in this research are data analysis, summarization and comparison. The data synthesis and analysis are the key value-added elements of this research, which could help to find out the relevant legislative system for the new forms of state attestation of graduates of higher medical school in Ukraine.

\section{REVIEW AND DISCUSSION}

This issue is not clearly spelled out in the scientific works of domestic researches. Kyryan in $[1 ; 2]$ identifies major trends in the development of the system of Ukrainian higher medical education of the XXth century. Osiychuk analyzes influence of Euro integration processes on the higher medical education development in Ukraine [3]. Humeniuk studies the issues of evaluation of medical higher education quality within the context of foreign students' education in Ukraine [4]. But nevertheless, the questions of search of new forms and methods of the state attestation of graduates of higher medical school are not highlighted in the research papers of Ukrainian scientists.

Foreign researches have this issue explored in a greater degree. One of the most effective and up-and-coming assessment methods for medical students, graduates and specialists is OSCE, proposed by H. Harden $[5 ; 6]$. Further literature review allows us to mention use of OSCE as a part of medical training on the principles of reliability and validity [7; 8]. Issues of OSCE implementation and evaluation within a variety of programs were analyzed in research papers of Brand and Schoonheim-Klein [9], Turner and Dankoski [10], Furlong [11], Major [12].

Thus, we see that the question of studying the legal profile for state certification of graduates of higher medical schools remains open.

The official substantiation (on the part of state departmental bodies) of the need for improvement state attestation of medical graduates of branch of study " 22 Health Protection" in the form of integrated state qualification exam can be reduced, with some considerations, to the following:

1) It is an identical, uniform attestation approach for determining the education level and quality of medical students. As a counterargument on this provision, we can talk about the non-use of the greatest possible effectiveness of the educational competition, provided by the national and foreign leading scientific and educational medical schools in this case. Averaged by standards equalization or yearning for it by the public authorities can deprive the originality and uniqueness of the highly professional doctors' training, as well as the unique competitive development of scientific and educational national medical schools, their prospects in competition with foreign colleagues (new methods, new scientific approaches, new developments, etc.).

2) It enables integration into the global medical and educational space. It's hard to argue with such motivation. But it should be noted that the trained specialists' focus on the external specialized labor markets should not be from top-down at the final stage of the educational process, but should be ensured by the creation of appropriate conditions in various directions throughout the specialist's training;

3) It is a part of anti-corruption component. In this part, it is disinclined to speak of objections. However, as other processes in Ukraine have shown, it is difficult to overcome corruption solely by such mechanisms, since in fact they received either geographical or qualitative transformation, or all its variations at once. The principle of intolerance to instances of corruption and co-optation, noted in government decisions on masters' attestation, is difficult to assess directly in the legal context.

Directly in the legal context, the relevance of the stated research topics for the national profile educational system of the healthcare academic discipline consists, in our opinion, at least in the pragmatic aspects faced by community. Firstly, we are talking about the novelty of the proposed form of medical students' attestation, because students have passed integrated state qualification exam in 2019 for the first time. The importance of consequences of such an innovation requires clearly established rules. Therefore, secondly, the proposed modernization requires carefully considered legal justification for such innovations.

What are the main documents of the special legal support in Ukraine for integrated state qualification exam in higher medical school, besides the basic provisions of the Constitution of Ukraine [13], as well as the constitutional legislation on education [14] and higher education [15]? The Ministry of Health of Ukraine in this matter refers primarily to decisions of the Government of Ukraine [16] as a managerial body in the field of higher education and operates on the constitutional special Law of Ukraine on Higher Education. On its official website the Office determines the legality of the state attestation of medical students by reference to Decree of the Cabinet of Ministers of Ukraine No. 344 dated $28^{\text {th }}$ of March 2018 [17] by which the relevant Procedure was approved (hereinafter - the Order). At the same time, the Order, based on the name, is targeted, i.e. it relates to master's training in the specialties of the field of knowledge "22 Health Care": 221 Dentistry; 222 Medicine; 223 Nursing; 224 Technologies for medical diagnostics and treatment; 225 Medical psychology; 226 Pharmacy, industrial pharmacy; 227 Physical therapy, occupational therapy; 228 Pediatrics; 229 Public health. The list of specialties in the field of health care is determined 
Table I. Legal enforcement for integrated state qualification exam of master's degree in discipline «22 Health Care»

\begin{tabular}{|c|c|c|}
\hline Legislative levels & Normative legal acts & Substantive aspects of regulation (with the growing importance) \\
\hline Constitutional & Constitution of Ukraine & $\begin{array}{l}\text { Right to education; } \\
\text { System of government; }\end{array}$ \\
\hline Constitutional laws & $\begin{array}{l}\text { Laws of Ukraine: } \\
\text { "On education", } \\
\text { "On higher education", }\end{array}$ & $\begin{array}{l}\text { - Implementation of constitutional right to education, including right to } \\
\text { higher education } \\
\text { - Implementation of constitutional right to higher education; } \\
\text { Attestation of candidates for higher education; } \\
\text { Possible attestation form of candidates for master's degree is the } \\
\text { integrated state qualification exam } \\
\text { - Legal personality of the Government in the educational sphere, } \\
\text { including higher education }\end{array}$ \\
\hline
\end{tabular}

Decree of the Cabinet of Ministers of Ukraine:

№ 684 dated 17.07.2019

The attestation form of medical master candidates' attestation was confirmed with special governmental legal regulation;

Ministry of Health of Ukraine was defined as the responsible public authority with the involvement of Ministry of Education and Science of Ukraine

Governmental № 354 dated 10.05.2018

- Integrated state qualification exam is for 9 academic specialties "22 Health Care" in the general list of 30 masters' specialties

№ 334 dated 28.03.2018

- The procedure of attestation is regulated in the form of qualification exam

Order of the Cabinet of Ministers of Ukraine:

№ 95-p dated 27.02.2019

- Program with the 10-year-term of realization, also providing for implementation of integrated state qualification exam as the attestation form of students' academic achievements

Orders of the Ministry of Health

Departmental

№ 419 dated 19.02.2019

№ 1883 dated 19.10 .2018

- Procedure and results of integrated state qualification exam is detailed - Financial and valuation issues of qualification exam

Source: composed by authors

by the Decree of the Cabinet of Ministers of Ukraine from $29^{\text {th }}$ of April, 2015 No. 266 [18].

The special normative legal acts in force for attestation of medical graduates should also include acts of the Ministry of Health of Ukraine, which are directly specified in the Order. These are two departmental orders $[19 ; 20]$ : first one regulates the procedural issues of organizing, conducting and evaluating attestation in the form of a qualification exam; the second one determines the cost of attestation, including the development phase.

Thus, national legislative levels, types of normative legal acts, and specific subject areas of legislative regulation as an element of legal enforcement for integrated state qualification exam in higher medical school can be comprehensively presented in Table I.

However, in our opinion, a systematic analysis of the legal enforcement, including legislative support, of the qualification exam for medical students allows us to highlight a number of legally problematic aspects.

So, the Decree of the Government was adopted at the end of March 2018, the official publication was made on May, 2018. At the same time, clause 1 of the Order determines its effect in relation to applicants who entered (recovered) in 2016. It is with the date indicated in the amended edition from 03.04.2019. But the students' attestation is a result of their training and educational process. Therefore, it is hardly possible to recognize as effective the modernization of higher medical education with the imperative to reform only attestation itself, leaving the preparation stage in the past. Therefore, the legal purity of such a decision can be called into question. For example, questions arise about the conformity of the above provision of Article 58 of the Constitution of Ukraine, the principle of the reverse action's inadmissibility in time of legislative acts. Furthermore, as it is about the legal personality of individuals as participants in the educational process, whether it is comply with the decision of the Constitutional Court of Ukraine No. 1-rp/99 dated 09.02.1999 [21]. Legal ways out of this situation (avoiding extreme, judicial) are simple: do not indicate the date (be guided by the general rules for the entry into force of regulatory legal acts) or indicate it in advance, for example, received (restored) in 2019/2020/ etc. Moreover, it looks strange, within the original wording, as well as the targeting of the normative legal act, an indication in it on the date for the masters below, in the text of the Order. In fact, the qualification exam's schedule for 2019, presented on the official website of the Ministry of Health of Ukraine, is inconsistent with the provision on the preparation of the "CROC" exam and professional English exam specifications no later than six months before the 
date of their conduct, as it is indicated in the Order of the department, which entered into force on 09.04.2019. The time countdown for an objective structured clinical exam (OSCE) is generally determined by reference (asterisk) in the order of the Ministry of Health of Ukraine No. 1883 dated 19.10.2018: from 01.01.2019 [20].

The Law of Ukraine "On Higher Education" presupposes the absence of imperativeness regarding the attestation form of persons who receive a master's degree, since the norm of the Law establishes that a single state qualification examination is a possible but not mandatory form of such attestation. There is no explanation of the motivation for the obligatory introduction of just such a form and just as an experiment in higher medical school. Moreover, clause 1 of the Decree and clause 2 of the Order approved by it contradict each other in this part, since the last one states that attestation can also be carried out in another form determined by the standard of higher education. In addition, there is no clear distinction between the respective powers of two ministries: the Ministry of Health of Ukraine and the Ministry of Education and Science of Ukraine.

The norms of the Order operate in three categories: "CROC", "CROC 1" and "CROC 2". The first document is defined as an integrated test exam. It can be carried out in one or two test stages, respectively, "CROC 1" and "CROC 2". However, the stages and required components of the qualification exam are associated exclusively with the last two categories. In fact, the legislative document, in addition to linking the stagedness of passing medical professional English, does not give any legal meaning to the CROC exam.

The Decree also establishes that the attestation form is an integrated state qualification exam, which consists of four components. But an analysis of the stages and mandatory components for separate specialties of the discipline " 22 Health Care" allows us to conclude that fewer components of attestation are admissible. For example, the specialty "225 Medical Psychology" presupposes two compulsory components of the qualification exam: CROC (in the text of the Appendix to Procedure CROC 1 and CROC 2) and professional English. Thus, legally prescribed phasing and mandatory elements of an integrated state qualification exam in the refraction of specific specialties do not fully correspond to a certain form of attestation of applicants for higher medical education. Of course, the underlying internal contradiction of the content of a normative legal act requires its elimination.

There are legal defects in the choice of exclusively English as a mandatory component of an integrated state qualification exam. The question itself, as is known, is more voluminous: the ratio of the compulsory nature of such an exam to the language of the educational process in higher education institutions in accordance with national legislation. Regarding the mandatory legally binding to English language, it is necessary to note that, as well as known, Ukraine declares its European integration intentions. And in this case, we must rely on linguistic pluralism, including official spheres. In this context, it is also worth paying attention to another technical nuance, the ambiguity of the published provisions: the Decree determines the transition to exam English from 01.09.2019, and the Ministry of Health of Ukraine on its official website declares this transition since 2020 [22].

Non-alternative payment for re-passing the qualification exam (paid by applicants), as determined by the Government, also raises legal issues. By setting such an opportunity, and in fact, the phasing of the qualification exam, applicants' attestation, providing the opportunity to retake the exam, the state includes such an opportunity in the right of the applicant, which can be transformed into a legal understanding of the competence of the subject to realize the right to higher education. Subject to the conditions of competitiveness, forms of ownership, etc., this legislative provision is contrary to Art. 53 of the Constitution of Ukraine and, accordingly, the decision of the Constitutional Court of Ukraine No. 5-rp/2000 dated 04.03.2014 [23]. Therefore, non-alternative payment for the applicant, without taking into account valid reasons for missing, could potentially be qualified as unlawful. Additional passing the exam proposed by the Ministry of Health of Ukraine in order No. 419 dated 19.02.2019 does not comply with the Order. There are no rules for passing the additional qualification exam in the text of the governmental document.

We can state that the professional legal level of providing an integrated state qualification exam leaves much to be desired. Unfortunately, this situation is aggravated by its ubiquity. Indeed, the ambiguous formulations in the governmental decisions, for example, regarding the mandatory nature of the proposed attestation form, the contradiction of each other with the regulatory provisions in this part are also confirmed in the texts of other relevant legislative documents. So, after the indicated alternative in the Decree, its obligatoriness is named here, among the basics and principles of the qualification exam. It should be reminded that the name of the Decree determines its scope: masters' attestation. However, both the text below and the differences in the indicated dates extend the scope of its action to specialists as well. Probably the differentiation of various levels of higher education in the applicants' attestation, with the corresponding legal support, is more productive.

The sequence and priority of the documents adopted by the Ministry of Health of Ukraine to ensure a qualification exam is, to put it mildly, perplexing: order No. 1883 dated 19.10.2018 has determined the financial component, and procedural issues of attestation have been established only in February 2019, and taking into account official publication, much later in April. This leads to conclusion: the main issue is departmental finances, and it is carried out ensuring the rights and interests of all other participants in the process. In the prioritization by the state body of the priorities, we would like to recall the content of Art. 1 of the Constitution of Ukraine that Ukraine is a sovereign and independent, democratic, social, legal state. In addition, the Ministry of Health of Ukraine is obliged to strictly comply with legal requirements and not allow itself 
the distribution of requirements and recommendations to the heads of higher education institutions, which are not in compliance with the law. Moreover, we would like to recall that the importance of legislation is in the first place, and among the expected results of the implementation of the Strategy for the Development of Medical Education in Ukraine: "The implementation of the Strategy will provide an opportunity to create a legislative basis for the further development of medical education in Ukraine, to implement comprehensive changes in this area" $[24 ; 25 ; 26]$.

\section{CONCLUSIONS}

In view of foregoing, we can make a conclusion that in the modern globalization world, competition of national educational services should be ensured by a range of different activities: legal, organizational, financial, etc. Thelegal direction, domestic rules should correspond to similar, uniform rules and practices of the most effective state (regional, international) systems. The effectiveness of this message is especially evident for the areas of knowledge and professions, their professional and educational support, which can be evaluated from the position of universal content. Medicine is a vivid confirmation of this. Indeed, fundamental medical standards are common civilizational values. Methods, approaches, high technology, including educational, reference points and levels of achievement may differ; but basic medical knowledge is universal. All this allows us to derive educational requirements for medicine to the best internal and external standards, which provides the opportunity to achieve the training of specialists in the relevant areas in a competitive section. In addition, it allows ensuring the subjective opportunities and rights of future qualified medical workers, as well as the interpenetration of the medical industry, its achievements in various "civilian registrations (registrations, incorporations)". An example of efficiency, in our opinion, can and should serve as the legal, including legislative, enforcement of higher medical education in the country, including attestation forms and procedures of applicants.

\section{REFERENCES}

1. Kyryan T. The analysis of evolutionary changes in the system of higher medical education in Ukraine in the first half of the XX-th century. EUREKA: Social and Humanities. 2016; 3: 53-58.

2. Kyryan T. Pryntsypy perebudovy vyshchoi osvity i vyshcha medychna shkola Ukrainy [Principles of transformation of higher education and higher medical school in Ukraine]. Scientific Journal «ScienceRise: Pedagogical Education». 2016; 6 (2): 26-30. (In Ukrainian).

3. Osiychuk M. S. Vplyv yevrointehratsiinykh protesiv na rozvytok vyshchoi medychnoi osvity [Influence of eurointegration processes on the higher medical education development]. Medical education. 2013;2:9-13. (In Ukrainian).

4. Harden R. M. What is an OSCE? Med. Teach. 1988; 10: 19-23.

5. Furlong E., Fox P., Lavin M., Collins R. Oncology nursing students'views of a modified OSCE. European Journal of Oncology Nursing. 2005; 9: 351-359.

6. Harden R., Stevenson W. et al. Assessment of clinical competence using objective structured clinical examination. British Medical Journal. 1975; 1 (5995): 447-451.
7. Konstytutsiia Ukrainy [Constitution of Ukraine] (28.06.1996). URL: https://zakon.rada.gov.ua/laws/show/254\%D0\%BA/96\%D0\%B2\%D1\%80 (In Ukrainian).

8. Wallenstein J., Heron S. et al. A core competency-based objective structured clinical examination (OSCE) can predict future resident performance. Academic Emergency Medicine. 2010; 17: 67-71.

9. Brand H. S., Schoonheim-Klein, M. Is the OSCE more stressful? Examination anxiety and its consequences in different assessment methods in dental education. European Journal of Dental Education. 2009; 13: 147-153.

10. Turner J. L., Dankoski M. E. Objective structured clinical exams: a critical review. Fam Med. 2008;40(8):574-578. Retrieved from: https://www. ncbi.nlm.nih.gov/pubmed/18988044.

11. Chesser A., Cameron H. et al. Sources of variation in performance on a shared OSCE station across four UK medical schools. Medical Education. 2009; 43: 526-532.

12. Major D. OSCEs - seven years on the bandwagon: The progress of an objective structured clinical evaluation programme. Nurse Education Today. 2005; 25: 442-454.

13. Humeniuk V. Otsiniuvannia yakosti vyshchoi medychnoi osvity u konteksti navchannia inozemnykh studentiv v Ukraini [Evaluation of medical higher education quality within the context of foreign students' education in Ukraine]. Comparatively pedagogic studio. 2013; 2-3(1617): 186-192. (In Ukrainian).

14. Zakon Ukrainy Pro osvitu vid 05.09.2017 № 2145-VIII [Law of Ukraine on education from 05.09.2017 № 2145-VIII]. URL: https://zakon.rada. gov.ua/laws/show/2145-19 (In Ukrainian).

15. Zakon Ukrainy Pro vyshchu osvitu vid 01.07.2014 № 1556-VII [Law of Ukraine on higher education from 01.07.2014 № 1556-VII]. URL: https:// zakon.rada.gov.ua/laws/show/1556-18 (In Ukrainian).

16. Zakon Ukrainy Pro Kabinet Ministriv Ukrainy vid 27.02.2014 № 794-VII [Law of Ukraine on Cabinet of Ministers from 27.02.2014 № 794-VII]. URL: https://zakon.rada.gov.ua/laws/show/794-18 (In Ukrainian).

17. Postanova Kabinetu Ministriv Ukrainy Pro zatverdzhennia Poriadku zdiisnennia yedynoho derzhavnoho kvalifikatsiinoho ispytu dlia zdobuvachiv stupenia vyshchoi osvity mahistr za spetsialnostiamy haluzi znan "22 Okhorona zdorov'ia" vid 28.03.2018 № 344 [Decree of Cabinet of Ministers of Ukraine on approval of the Procedure of the state integrated qualification exam for applicants of masters' degree of academic specialty "22 Health care" from 28.03.2018 № 344]. URL: https://zakon.rada.gov.ua/laws/show/334-2018-\%D0\%BF (In Ukrainian).

18. Postanova Kabinetu Ministriv Ukrainy Pro zatverdzhennia pereliku haluzei znan i spetsialnostei, za yakymy zdiisniuietsia pidhotovka zdobuvachiv vyshchoi osvity vid 29.04.2015 № 266 [Decree of Cabinet of Ministers of Ukraine on approval of the list of knowledge and specialties, in accordance with which the training of applicant for higher education is realized from 29.04.2015 № 266]. URL: https://zakon.rada.gov.ua/laws/show/266-2015-\%D0\%BF\#n11 (In Ukrainian).

19. Nakaz Ministerstva okhorony zdorov'ia Ukrainy Pro zatverdzhennia Poriadku, umov ta strokiv rozroblennia i provedennia yedynoho derzhavnoho kvalifikatsiinoho ispytu ta kryteriiv otsiniuvannia rezultativ vid 19.02.2019 № 419 [Order of Ministry of Health of Ukraine on approval of the Procedure, conditions and terms of developing and holding the state integrated qualification exam and criterion for results' assesment from 19.02.2019 № 419]. URL: https://zakon.rada.gov.ua/laws/show/ 20279-19\#n14 (In Ukrainian). 
20. Nakaz Ministerstva okhorony zdorov'ia Ukrainy Pro zatverdzhennia Metodyky rozrakhunku vartosti rozrobky ta provedennia yedynoho derzhavnoho kvalifikatsiinoho ispytu vid 19.10.2018 № 1883 [Order of Ministry of Health of Ukraine on approval of the Methodology for calculating cost of developing and holding the state integrated qualification exam from 19.10.2018 № 1883]. URL: https://zakon.rada. gov.ua/laws/show/z1486-18\#n14 (In Ukrainian).

21. Rishennia Konsytutsiinoho Sudu Ukrainy u spravi za konstytutsiinym zvernenniam Natsionalnoho banku Ukrainy shchodo ofitsiinoho tlumachennia polozhennia chastyny pershoi statti 58 Konstytutsii Ukrainy (sprava pro zvorotnu diiu v chasi zakoniv ta inshykh normatyvno-pravovykh aktiv) vid 09.02.1999 № 1-pп/99 [Decision of the Constitutional Court of Ukraine in the case of the constitutional appeal of the National Bank of Ukraine regarding the official interpretation of the provisions of Article 58.1 of the Constitution of Ukraine (case of retroactive effect in time of laws and other regulations) from 09.02.1999 № 1-pп/99]. URL: https://zakon.rada.gov.ua/laws/ show/v001p710-99\#n54 (In Ukrainian).

22. Ministerstvo okhorony zdorov'ia Ukrainy: ofitsiinyi web-sait [Ministry of Health of Ukraine: official web-site]. URL: https://moz.gov .ua / edki (In Ukrainian).

23. Rishennia Konsytutsiinoho Sudu Ukrainy u spravi za konstytutsiinym podanniam 50 narodnykh deputativ Ukrainy pro ofitsiine tlumachennia polozhen chastyny tretoi statti 53 Konstytutsii Ukrainy «derzhava zabezpechuie dostupnist i bezoplatnist doshkilnoi, povnoi zahalnoi serednoi, profesiino-tekhnichnoi, vyshchoi osvity v derzhavnykh i komunalnykh navchalnykh zakladakh» (sprava pro dostupnist i bezoplatnist 0svity) vid 04.03.2014 № 5-pп/2000 [Decision of the Constitutional Court of Ukraine in the case of the constitutional submission of 50 People's Deputies of Ukraine on the official interpretation of the provisions of part three of Article 53 of the Constitution of Ukraine "the state ensures the accessibility and free of charge of pre-school, full general secondary, vocational and technical higher education in state and communal educational institutions" (the case of accessibility and free of charge) education) from 04.03.2014 № 5-pп/2000]. URL: https://zakon.rada.gov.ua/laws/show/v001p71099\#n54 (In Ukrainian).

24. Rozporiadzhennia Kabinetu Ministriv Ukrainy Pro skhvalennia Stratehii rozvytku medychnoi osvity v Ukraini vid 27.02.2019 № 95-p [Order of Cabinet of Ministers of Ukraine On approval of the Strategy of development of medical education in Ukraine from 27.02.2019 № 95p]. URL: https://zakon.rada.gov.ua/laws/show/95-2019-\%D1\%80 (In Ukrainian).
25. Postanova Kabinetu Ministriv Ukrainy Pro Deiaki pytannia atestatsii osib, yaki zdobuvaiut stupin mahistra, u formi yedynoho derzhavnoho kvalifikatsiinoho ispytu vid 17.07.2019 № 684 [Decree of Cabinet of Ministers of Ukraine on Some questions of certification of the persons receiving the master's degree, in the form of the uniform state qualification examination from 17.07.2019 № 684]. URL: https://zakon. rada.gov.ua/laws/show/684-2019-\%D0\%BF (In Ukrainian).

26. Postanova Kabinetu Ministriv Ukrainy Pro zatverdzhennia pereliku spetsialnostei, za yakymy provodytsia yedynyi derzhavnyi kvalifikatsiinyi ispyt dlia zdobuttia stupenia mahistra vid 10.05.2018 № 354 [Decree of Cabinet of Ministers of Ukraine on approval of the list of specialties by which the state integrated qualification examination is conducted for the master's degree from 10.05.2018 № 354]. URL: https://zakon. rada.gov.ua/laws/show/354-2018-\%D0\%BF\#n8 (In Ukrainian).

This paper is drafted within the scientific and research activity "Strategic directions of modernization of Ukrainian economics and its regions" (№ 0114 U001554 Odessa national I. I. Mechnikov University).

\section{ORCID and contributorship:}

Valeria G. Marrichereda - 0000-0002-1611-3654 ${ }^{A, F}$

Svitlana B.Melnyk - 0000-0003-1117-0729 B,D

Viktoriia I. Borshch - 0000-0001-9106-9078 ${ }^{B, D}$

Olena O. Terzi - 0000-0003-4120-6526 ${ }^{B}$

Natalia A. Lyakhova - 0000-0003-0503-9935 ${ }^{\mathrm{E}}$

\section{Conflict of interest:}

The Authors declare no conflict of interest.

\section{CORRESPONDING AUTHOR Viktoriia I. Borshch}

Department of management and innovations

Odesa national I. I. Mechnikov university

24/26 Frantsuzkyi bulvar, Odesa, 65058, Ukraine

tel: +380971473003

e-mail: viktoriyaborshch@gmail.com

Received: 17.02 .2020

Accepted: 05.05.2020 